\title{
Pulmonary hypertension diagnosed by right heart catheterisation in sickle cell disease
}

\author{
G.H.H. Fonseca*, R. Souza", V.M.C. Salemi" ${ }^{\star}$, C.V.P. Jardim" ${ }^{\#}$ and S.F.M. Gualandro*
}

ABSTRACT: Recent studies have recognised the importance of pulmonary hypertension $(\mathrm{PH})$ in sickle cell disease (SCD). The aim of this study was to determine the prevalence and prognostic impact of $\mathrm{PH}$ and its features in patients with SCD.

80 patients with SCD underwent baseline clinical evaluation, laboratory testing, 6-min walk tests (6MWTs) and echocardiography. Patients with a peak tricuspid regurgitant jet velocity (TRV) of $\geqslant 2.5 \mathrm{~m} \cdot \mathrm{s}^{-1}$ were further evaluated through right heart catheterisation (RHC) to assure the diagnosis of $\mathrm{PH}$.

Our study evidenced a $40 \%$ prevalence of patients with elevated TRV at echocardiography. RHC (performed in 25 out of 32 patients) confirmed PH in 10\% (95\% Cl 3.4-16.5\%) of all patients, with a prevalence of post-capillary $\mathrm{PH}$ of $6.25 \%(95 \% \mathrm{Cl} 0.95-11.55 \%)$ and pre-capillary $\mathrm{PH}$ of $3.75 \%$ (95\% $\mathrm{Cl}-0.4-7.9 \%)$. Patients with PH were older, had worse performance in 6MWTs, and more pronounced anaemia, haemolysis and renal dysfunction. Survival was shorter in patients with PH.

Our study reinforced the use of echocardiography as a screening tool for PH in SCD and the mandatory role of RHC for proper diagnosis. Our findings confirmed the prognostic significance of PH in SCD as its association to pronounced haemolytic profile.

KEYWORDS: Haemodynamics, prevalence, pulmonary hypertension, right heart catheterisation, sickle cell disease, survival

ickle cell disease (SCD) encompasses a group of hereditary haemoglobinopathies resulting from inheritance of at least one mutant version of the $\beta$-globin gene $(\beta A)$ on chromosome 11, designated haemoglobin $\mathrm{S}(\mathrm{HbS})$ [1]. In $\mathrm{HbS}$, valine replaces glutamic acid in position 6 of the $\beta$-chain. This substitution leads to polymerisation of haemoglobin when it is deoxygenated [2].

In homozygous sickle cell anaemia (SCA), two $\beta S$-globin alleles are inherited. In addition to SCA, other major sickle genotypes resulting from co-inheritance of other $\beta A$-globin gene mutations or $\beta$-thalassaemia mutations are recognised [1]. Individuals who have SCA are clinically indistinguishable from those who have $S \beta 0$ thalassaemia and both are more severe than other sickle genotypes [1]. SCD is characterised clinically by the presence of chronic haemolytic anaemia and acute and chronic vaso-occlusion phenomena with cumulative and widespread organ damage. The World Health Organization (WHO) estimates there are $\sim 275,000$ births per year worldwide with SCD [3].
Pulmonary hypertension $(\mathrm{PH})$ associated with SCD was first described in 1936 by YATER and HANSMANN [4], and corresponds to a frequent and serious complication associated with increased morbidity and mortality. Traditionally, PH in SCD was considered to be a result of vaso-occlusive events, such as acute chest syndrome (ACS) $[5,6]$. In the last few years, however, $\mathrm{PH}$ has been attributed to intravascular haemolysis and consequent deregulated nitric oxide metabolism $[7,8]$.

The early symptoms of $\mathrm{PH}$ are nonspecific and do not differ from those experienced by SCD patients without PH [9]. Previous studies suggested that the prevalence of $\mathrm{PH}$ in this disease is between 0 and 35\% [10-14]. However, these studies were limited by their retrospective data collection, patient selection, and lack of right heart catheterisation (RHC) to confirm the presence of $\mathrm{PH}$ and differentiate pre- from postcapillary $\mathrm{PH}$.

The aim of this study was to determine the prevalence and prognostic significance of $\mathrm{PH}$ in SCD patients.
AFFILIATIONS

*Hematology Dept,

\#Pulmonary Dept, Heart Institute, and

"Cardiology Dept, Heart Institute, University of Sao Paulo Medical School, São Paolo, Brazil.

\section{CORRESPONDENCE}

G.H.H. Fonseca

Hematology Dept

University of São Paulo Medical School

Av. Dr. Eneas de Carvalho Aguiar $155-1^{\circ}$ andar

São Paulo

05403-000 Brazil

E-mail: ghhencklain@uol.com.br

Received:

Aug 202010

Accepted after revision:

May 102011

First published online:

July 202011 


\section{METHODS}

\section{Population}

In this cohort, we prospectively evaluated 80 consecutive adult patients ( $>18$ yrs of age) with SCD (subtypes SCA and S $\beta 0$ thalassaemia) followed at our university hospital (Hospital das Clínicas, University of São Paulo Medical School, São Paulo, Brazil). The diagnosis of SCD was based on haemoglobin electrophoresis and A2 haemoglobin level determination by chromatography. To be included, patients had to be clinically stable, without history of ACS or blood transfusion in the previous 2 weeks. All patients provided written informed consent.

\section{Clinical and laboratorial evaluation}

All patients underwent baseline clinical evaluation and haematological testing, including complete blood count, reticulocyte count, haemoglobin electrophoresis, fetal haemoglobin level determination and biochemical testing to evaluate their haemolytic profile. History of ACS was assessed from medical records. The serum levels of inflammatory markers, and liver and renal function were also determined. On the same day, all patients performed a 6-min walk test (6MWT), as previously described [15].

\section{Echocardiographic studies}

All Doppler echocardiography was performed by the same cardiologist, who was blinded to all other patient data except the diagnosis of SCD. The two-dimensional echocardiographic images were obtained using a Sequoia 512 ultrasound system (Acuson, Mountain View, CA, USA). Cardiac measurements were performed according to the guidelines of the American Society of Echocardiography [16]. Tricuspid regurgitation was assessed in the parasternal right ventricular inflow, parasternal short-axis and apical four-chamber views. Continuous-wave Doppler sampling of the peak tricuspid regurgitant jet velocity (TRV) was used to estimate the right ventricular-to-right atrial systolic pressure gradient using the modified Bernouille equation $\left(4 \times \mathrm{TRV}^{2}\right)$. The presence of valvular heart disease or left ventricular systolic dysfunction was an exclusion criterion.

\section{Invasive haemodynamic evaluation}

RHC was performed in patients with a TRV of $\geqslant 2.5 \mathrm{~m} \cdot \mathrm{s}^{-1}$. A 7 French flow-directed pulmonary artery catheter (Baxter Healthcare Corporation, Irvine, CA, USA) was used in all patients. Cardiac output (CO) was measured by the standard thermodilution technique. We defined $\mathrm{PH}$ as the presence of a

TABLE 1 Sickle cell disease patient characteristics, according to tricuspid regurgitant jet velocity (TRV)

\begin{tabular}{|c|c|c|c|c|}
\hline & Baseline data & TRV $<2.5 \mathrm{~m} \cdot \mathrm{s}^{-1}$ & $\mathrm{TRV} \geqslant 2.5 \mathrm{~m} \cdot \mathrm{s}^{-1}$ & p-value \\
\hline Subjects $\mathrm{n}$ & 80 & 48 & 32 & \\
\hline Age yrs & $33 \pm 10$ & $30 \pm 8$ & $38 \pm 11$ & 0.001 \\
\hline Females \% & 61.2 & 68.7 & 50 & 0.07 \\
\hline BMI $\mathbf{k g} \cdot \mathrm{m}^{-2}$ & $20.6 \pm 2.6$ & $21.1 \pm 2.8$ & $20 \pm 2.3$ & 0.6 \\
\hline Left ventricle ejection fraction \% & $64 \pm 7$ & $64 \pm 7$ & $64 \pm 6$ & 0.67 \\
\hline \multicolumn{5}{|l|}{ Clinical history \% } \\
\hline Hydroxyurea use & 13.7 & 18.7 & 6.2 & 0.102 \\
\hline Priapism & 70.9 & 62.5 & 80 & 0.18 \\
\hline Hepatitis C & 27.5 & 16.6 & 34.3 & 0.04 \\
\hline Leg ulcer & 30 & 12.5 & 50 & 0.001 \\
\hline Proteinuria & 36.2 & 25 & 40.6 & 0.06 \\
\hline \multicolumn{5}{|l|}{ Haematological findings } \\
\hline $\mathrm{Hb} g \cdot L^{-1}$ & $82 \pm 12.9$ & $86.7 \pm 16.1$ & $75.5 \pm 12.1$ & $<0.001$ \\
\hline Reticulocytes \% & $11.2 \pm 5.43$ & $10.9 \pm 5.33$ & $11.8 \pm 5.65$ & 0.51 \\
\hline Leukocytes $\times 10^{9}$ cells $\cdot L^{-1}$ & $11.4 \pm 3.4$ & $11 \pm 3.5$ & $12.1 \pm 3.2$ & 0.11 \\
\hline Platelets $\times 10^{9}$ cells $\cdot \mathrm{L}^{-1}$ & $407 \pm 124$ & $427 \pm 121$ & $378 \pm 126$ & 0.082 \\
\hline Fetal $\mathrm{Hb} \%$ & $7.4 \pm 5.41$ & $8.29 \pm 5.78$ & $6.22 \pm 4.64$ & 0.15 \\
\hline $\mathrm{LDH} U \cdot \mathrm{L}^{-1}$ & $1116 \pm 553$ & $909 \pm 445$ & $1427 \pm 561$ & $<0.001$ \\
\hline Uric acid $\mathrm{mmol} \cdot \mathrm{L}^{-1}$ & $332.5 \pm 125$ & $290 \pm 100$ & $390 \pm 112$ & 0.001 \\
\hline AST $U \cdot L^{-1}$ & $48.8 \pm 20.7$ & $42.6 \pm 17.6$ & $54.9 \pm 22.6$ & 0.007 \\
\hline GGT U $L^{-1}$ & $89.7 \pm 62.3$ & $71 \pm 64.5$ & $120 \pm 45.6$ & $<0.001$ \\
\hline Unconjugated bilirubin $\mu \mathrm{mol} \cdot \mathrm{L}^{-1}$ & $53.1 \pm 50.44$ & $53.35 \pm 56.4$ & $53.7 \pm 41.9$ & 0.211 \\
\hline C-reactive protein $\mathrm{ng} \cdot \mathrm{mL}^{-1}$ & $6.4 \pm 7.7$ & $5.3 \pm 5.5$ & $7.98 \pm 9.92$ & 0.36 \\
\hline
\end{tabular}

Data are presented as mean $\pm \mathrm{SD}$, unless otherwise stated. BMI: body mass index; 6MWT: 6-min walk test; DVT: deep venous thrombosis; ACS: acute chest syndrome; $\mathrm{Hb}$ : haemoglobin; LDH: lactate dehydrogenase; AST: aspartate transaminase; GGT: $\gamma$-glutamyltransferase; BUN: blood urea nitrogen. 
mean pulmonary artery pressure of $\geqslant 25 \mathrm{mmHg}$. Further classification into pre- or post-capillary $\mathrm{PH}$ was based on pulmonary artery occlusion pressure $(P$ pao). $\mathrm{PH}$ patients with a $P$ pao of $\leqslant 15 \mathrm{mmHg}$ were classified as having pre-capillary $\mathrm{PH}$. All patients presenting with $\mathrm{PH}$ at $\mathrm{RHC}$ were evaluated for the presence of chronic thromboembolic disease by means of pulmonary ventilation/perfusion $\left(V^{\prime} / Q^{\prime}\right)$ scan.

\section{Statistical analysis}

Continuous data are presented as mean \pm SD. Qualitative data are presented as proportions with $95 \%$ confidence intervals (CIs) and were compared using Fisher's exact test. All continuous variables were compared using unpaired t-tests. Laboratory measurements were log-transformed in order to reduce the influence of data distribution. A p-value of $<0.05$ was considered significant. Survival time was estimated using the Kaplan-Meier method. The log-rank test was used for curve comparison.

\section{RESULTS}

80 patients were included in the study $(61.2 \%$ females) with mean age of $33.3 \pm 10.1$ yrs. Median follow-up time was 31.9 months (range 3.3-34.6 months). An interpretable TRV was obtained in all patients and ranged between 0.79 and $4.17 \mathrm{~m} \cdot \mathrm{s}^{-1}$. In $32(40 \%, 95 \%$ CI $29.2-54.7 \%)$ patients, TRV was $>2.5 \mathrm{~m} \cdot \mathrm{s}^{-1}$, suggesting the presence of elevated pulmonary arterial systolic pressure (Ppas). Clinical, haematological, biochemical and echocardiographic characteristics of all patients are presented in table 1 . Patients with a TRV of $\geqslant 2.5$ $\mathrm{m} \cdot \mathrm{s}^{-1}$ presented more pronounced anaemia, more haemolysis (reflected by increased levels of lactate dehydrogenase (LDH) and aspartate transaminase), and higher levels of uric acid, $\gamma$ glutamyltransferase, blood urea nitrogen (BUN) and creatinine.

Among 32 patients referred for RHC, 26 (81.2\%) underwent the procedure. Four patients did not perform the exam for social or clinical reasons. Two patients refused the procedure. Haemodynamic data are showed in table 2 .

The $P$ pas estimated by echocardiography and measured by RHC were well correlated $(\mathrm{r}=0.77, \mathrm{p}<0.001)$; however, invasive

\begin{tabular}{|c|c|c|c|}
\hline \multirow[t]{2}{*}{ TABLE 2} & \multicolumn{3}{|c|}{$\begin{array}{l}\text { Invasive haemodynamic data, according to the } \\
\text { presence of pulmonary hypertension }(\mathrm{PH})\end{array}$} \\
\hline & Without PH & PH & $\mathrm{p}$-value \\
\hline Subjects n & 18 & 8 & \\
\hline Age yrs & $35.3 \pm 11.6$ & $45.6 \pm 10.7$ & 0.04 \\
\hline PVR Wood units & $0.8 \pm 0.6$ & $2.24 \pm 1.5$ & 0.002 \\
\hline $\begin{array}{l}\text { Cardiac index } \\
\mathrm{L} \cdot \mathrm{min}^{-1} \cdot \mathrm{m}^{-2}\end{array}$ & $5 \pm 1.36$ & $4.9 \pm 1.7$ & 0.85 \\
\hline Ppao $\mathrm{mmHg}$ & $13.3 \pm 2$ & $16 \pm 5.7$ & 0.07 \\
\hline Ppas $\mathrm{mmHg}$ & $28.5 \pm 4.5$ & $48.1 \pm 13.3$ & $<0.001$ \\
\hline $\bar{P}_{\text {pa }} \mathrm{mmHg}$ & $18.7 \pm 2.8$ & $33.1 \pm 8.9$ & $<0.001$ \\
\hline 6MWT m & $511 \pm 78.9$ & $460 \pm 152$ & 0.25 \\
\hline \multicolumn{4}{|c|}{$\begin{array}{l}\text { Data are presented as mean } \pm \mathrm{SD} \text {, unless otherwise stated. PVR: pulmonary } \\
\text { vascular resistance; } P \text { pao: pulmonary artery occlusion pressure; Ppas: pulmon- } \\
\text { ary artery systolic pressure; } \bar{P} \text { pa: mean pulmonary artery pressure; } 6 \mathrm{MWT} \text { : 6-min } \\
\text { walk test. }\end{array}$} \\
\hline
\end{tabular}

measurement confirmed the presence of elevated pulmonary artery pressure in only eight out of the 26 patients submitted to the procedure, corresponding to $10 \%$ of the total sample $(95 \% \mathrm{CI}$ $3.4-16.5 \%)$. Of these, five $(6.2 \%$, 95\% CI $0.9-11.5 \%)$ patients presented with a $P$ pao of $>15 \mathrm{mmHg}$, thus being classified as post-capillary hypertension; the remaining three $(3.7 \%, 95 \% \mathrm{CI}$ $0.4-7.9 \%$ ) patients were classified as having pre-capillary (arterial) pulmonary hypertension. Patient distribution according to echocardiographic and invasive haemodynamic characteristics is presented in figure 1.

The comparison between patients with true $\mathrm{PH}(\mathrm{n}=8)$ and the remaining patients from our cohort $(n=66)$ revealed a significant difference in age, distance walked in the $6 \mathrm{MWT}$, presence of proteinuria, platelets count, and BUN, LDH, uric acid, $\gamma$-glutamyltransferase and haemoglobin levels (table 3). Although the number of patients in each subgroup precluded further evaluation, no significant difference was found in the comparison of clinical and haemodynamic variables between patients with pre- and post-capillary $\mathrm{PH}$, except for $P$ pao (data not shown). It is noteworthy that all confirmed PAH patients presented pulmonary vascular resistances (PVRs) $>2.5$ Wood

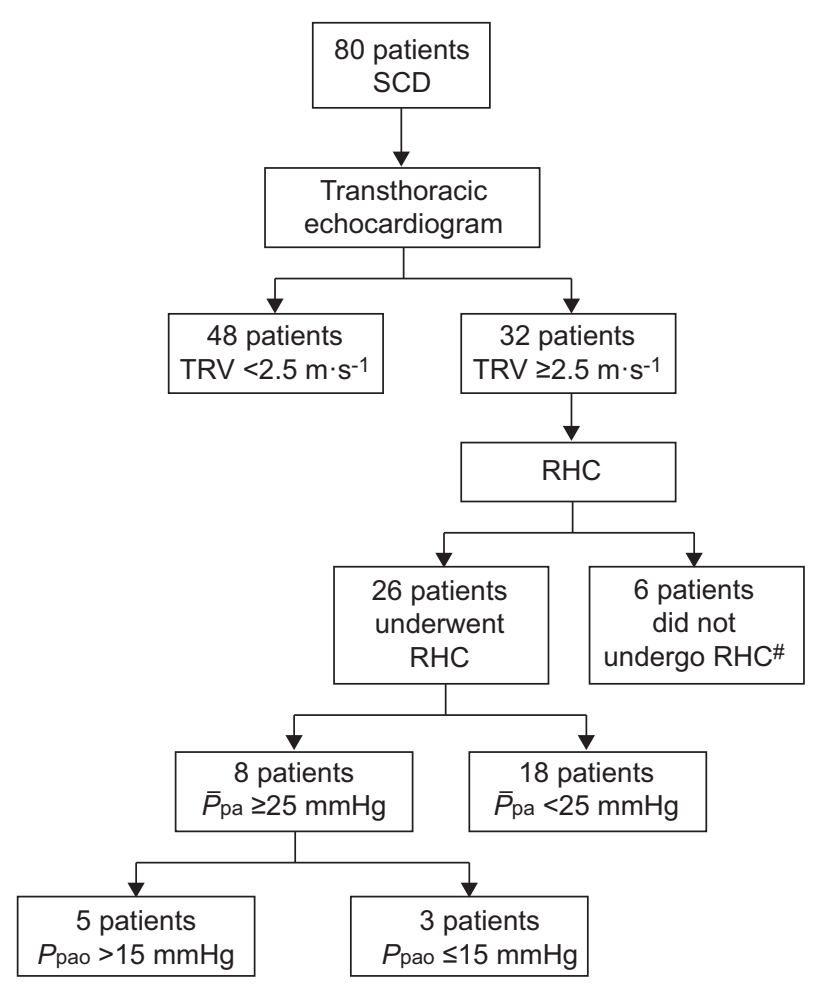

FIGURE 1. Patient distribution according to echocardiographic and invasive haemodynamic characteristics. SCD: sickle cell disease; TRV: peak tricuspid regurgitant jet velocity; RHC: right heart catheterisation; $\bar{P}$ pa: mean pulmonary artery pressure; Ppao: pulmonary artery occlusion pressure. \#: reasons for failure to perform RHC were either clinical (hyperhaemolytic reaction in a 28-yr-old female with a TRV of $3.05 \mathrm{~m} \cdot \mathrm{s}^{-1}$, alloimmunisation and severe anaemia in steady state in a 36-yr-old female with a TRV of $3.9 \mathrm{~m} \cdot \mathrm{s}^{-1}$, and infection in a 21-yr-old male with a TRV of $2.61 \mathrm{~m} \cdot \mathrm{s}^{-1}$ ), patient refusal (a 37-yr-old female with a TRV of $2.65 \mathrm{~m} \cdot \mathrm{s}^{-1}$ and a 40yr-old male with a TRV of $2.7 \mathrm{~m} \cdot \mathrm{s}^{-1}$ ) or social problems (a 45-yr-old male with a TRV of $\left.3.37 \mathrm{~m} \cdot \mathrm{s}^{-1}\right)$. 
TABLE 3 Sickle cell disease patient characteristics, according to the right heart catheterisation

TRV $<2.5 \mathrm{~m} \cdot \mathrm{s}^{-1}$ plus TRV $\geqslant 2.5 \mathrm{~m} \cdot \mathrm{s}^{-1}$
and $\overline{\mathrm{P} p a}<25 \mathrm{mmHg}$

\begin{tabular}{|c|c|c|c|}
\hline Subjects $n$ & 66 & 8 & \\
\hline Age yrs & $31.3 \pm 11.6$ & $45.6 \pm 11$ & 0.04 \\
\hline Females \% & 64.6 & 37.5 & 0.3 \\
\hline $\mathrm{BMI} \mathbf{k g} \cdot \mathrm{m}^{-2}$ & $20.8 \pm 2.65$ & $20.1 \pm 2.8$ & 0.5 \\
\hline Left ventricle ejection fraction \% & $64.2 \pm 7.1$ & $62.5 \pm 6$ & 0.53 \\
\hline 6MWT m & $53 \pm 71$ & $460 \pm 152$ & 0.02 \\
\hline $\mathrm{O}_{2}$ saturation $\%$ & $92.1 \pm 6.12$ & $87.5 \pm 7.41$ & 0.77 \\
\hline Priapism & 62.5 & 80 & 0.47 \\
\hline Hepatitis C & 24.6 & 25 & 0.33 \\
\hline Leg ulcer & 23.1 & 37.5 & 0.41 \\
\hline Proteinuria & 30.7 & 87.5 & 0.02 \\
\hline DVT & 7.7 & 37.5 & 0.04 \\
\hline Ischaemic stroke & 15.4 & 0 & 0.22 \\
\hline Reticulocytes \% & $11 \pm 5.3$ & $13.5 \pm 6.5$ & 0.23 \\
\hline Platelets $\times 10^{9}$ cells $\cdot \mathrm{L}^{-1}$ & $420 \pm 122$ & $308 \pm 137$ & 0.02 \\
\hline Fetal $\mathrm{Hb} \%$ & $7.8 \pm 5.7$ & $6.21 \pm 3.44$ & 0.9 \\
\hline $\mathrm{LDH} U \cdot \mathrm{L}^{-1}$ & $1041 \pm 535$ & $1596 \pm 424$ & 0.006 \\
\hline Uric acid $\mathrm{mmol} \cdot \mathrm{L}^{-1}$ & $282.5 \pm 109$ & $516 \pm 81.5$ & $<0.001$ \\
\hline AST $U \cdot L^{-1}$ & $46.3 \pm 18.8$ & $61.2 \pm 25.5$ & 0.04 \\
\hline GGT U.L-1 & $82.2 \pm 61.7$ & $135 \pm 64.3$ & 0.34 \\
\hline Unconjugated bilirubin $\mu \mathrm{mol} \cdot \mathrm{L}^{-1}$ & $55.7 \pm 28$ & $72.84 \pm 65$ & 0.22 \\
\hline C-reactive protein $\mathrm{ng} \cdot \mathrm{mL}^{-1}$ & $5.28 \pm 5.5$ & $6.36 \pm 4$ & 0.61 \\
\hline $\mathrm{BUN} \mathrm{mmol} \cdot \mathrm{L}^{-1}$ & $7.74 \pm 3.57$ & $18.6 \pm 11.5$ & $<0.001$ \\
\hline Creatinine $\mu \mathrm{mol} \cdot \mathrm{L}^{-1}$ & $56.6 \pm 21.1$ & $99 \pm 45.9$ & $<0.001$ \\
\hline
\end{tabular}

\section{Subjects $\mathbf{n}$}

6MWT $\mathrm{m}$

$\mathrm{O}_{2}$ saturation \%

Hydroxyurea use

Priapism

Proteinuria

Ischaemic stroke

Haematological findings

$\mathrm{Hb} \mathrm{g} \cdot \mathrm{L}^{-1}$

Reticulocytes \%

P $\times 10^{9}$ cells.

Uric acid $\mathrm{mmol} \cdot \mathrm{L}^{-1}$

GGT U.L-1

Unconjugated bilirubin $\mu \mathrm{mol} \cdot \mathrm{L}^{-1}$

BUN $\mathrm{mmol} \cdot \mathrm{L}^{-1}$

Creatinine $\mu \mathrm{mol} \cdot \mathrm{L}^{-1}$
$\bar{P}$ pa $\geqslant 25 \mathrm{mmHg}$

p-value units. Chronic thromboembolic disease was excluded in all patients by means of pulmonary $V^{\prime} / Q^{\prime}$ scanning.

Seven patients died during the follow-up period (table 4): two in the group with a TRV of $<2.5 \mathrm{~m} \cdot \mathrm{s}^{-1}$ and five in the group with a TRV of $\geqslant 2.5 \mathrm{~m} \cdot \mathrm{s}^{-1}$. In the latter group, three patients had been submitted for RHC: two presenting as post-capillary PH and the other one presenting as pre-capillary $\mathrm{PH}$. Although there was a trend toward a survival difference between the two groups classified according to the presence of a TRV of $\geqslant 2.5 \mathrm{~m} \cdot \mathrm{s}^{-1}$, it did not quite reach statistical significance $(p=0.07)$ (fig. 2). Patients with $\mathrm{PH}$ confirmed by RHC had worse survival compared with the remaining patients, regardless of their measured TRV ( $\mathrm{p}=0.0005)$ (fig. 3).

\section{DISCUSSION}

Our study was the first prospective study to estimate the prevalence and prognostic significance of pulmonary hypertension in SCD patients based on RHC. Our results indicated that SCD patients with $\mathrm{PH}$ presented worse clinical, laboratory and functional profiles, associated with a worse prognosis.

Clinical and echocardiographic characteristics of our population are similar to others previously described [10, 11, 13-15]. Approximately $40 \%$ of our patients presented with a TRV of $\geqslant 2.5 \mathrm{~m} \cdot \mathrm{s}^{-1}$, and this subgroup presented more anaemia, haemolysis and renal dysfunction compared with the group with a normal TRV. Similarly to the literature, there is no difference between the two groups by fetal haemoglobin level, vaso-occlusive episodes and ACS.

This specific subgroup of patients has previously been described as presenting a higher mortality. These results have been ascribed to increased prevalence of $\mathrm{PH}$ in this population $[7,8,13]$. Nevertheless, the presence of $\mathrm{PH}$ was solely addressed by echocardiography in these previous studies. Our findings lead us to speculate that the higher mortality associated with a TRV of $\geqslant 2.5 \mathrm{~m} \cdot \mathrm{s}^{-1}$ may not totally be related to the presence of 


\begin{tabular}{|c|c|c|c|c|c|c|}
\hline 2 & M & 37 & 1.16 & $N A^{\#}$ & $N A^{\#}$ & Spontaneous intracranial haemorrhage \\
\hline 3 & $\mathrm{~F}$ & 65 & 3.32 & 28 & 12 & Chronic renal failure \\
\hline 4 & $\mathrm{~F}$ & 36 & 3.9 & $N A^{\#}$ & $N A^{\#}$ & Acute anaemia, pneumonia \\
\hline 6 & M & 51 & 3.37 & 40 & 18 & Right ventricular dysfunction, pneumonia \\
\hline 7 & M & 58 & 4.17 & 43 & 8 & Right ventricular dysfunction \\
\hline
\end{tabular}

TRV: tricuspid regurgitant jet velocity; $\bar{P}$ pa: mean pulmonary artery pressure; Ppao: pulmonary artery occlusion pressure; F: female; M: male; NA: not applicable. ${ }^{\#}$ : right heart catheterisation was not performed; in this case, patients were included in the survival analysis based on the results of the echocardiogram.

PH but may also be associated with other pathophysiological phenomena of SCD.

Furthermore, invasive haemodynamics revealed a higher prevalence of a post-capillary component $(P$ pao $>15 \mathrm{mmHg})$ in the subgroup of patients with true $\mathrm{PH}$, indicating a possible underlying left ventricular dysfunction.

In 2003, CASTRO et al. [17] also reported a large proportion of patients (50\%) with high $P$ pao (>15 $\mathrm{mmHg}$ ), despite the normal ejection fraction in echocardiography. In 2007, ANTHI et al. [18] found a prevalence of $46.2 \%$ of venous (post-capillary) hypertension among patients with SCD and PH. In a recent study, using only echocardiography, SACHDEV et al. [19] reported a left heart disease prevalence of $10-11 \%$ in SCD patients with $\mathrm{PH}$. Although the increased Ppao was once attributed to an "inversed" Bernheim effect (left ventricular filling inhibition by paradoxical ventricular septal motion) [17], the most probable explanation is an underlying diastolic dysfunction. Diastolic dysfunction is well described in SCD and is imputed to microvascular occlusion, iron overload and chronic high output [19].

Consequently, our findings reinforced the multifactorial mechanisms that may be related to the development of $\mathrm{PH}$ in SCD patients. Among those multiple mechanisms, haemolysis,

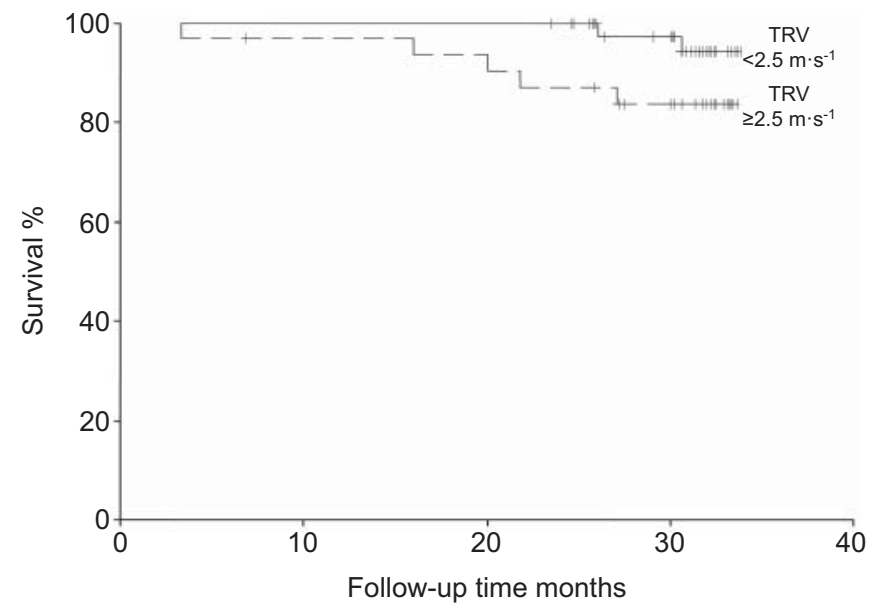

FIGURE 2. Probability of survival according to tricuspid regurgitant jet velocity (TRV) group. Kaplan-Meier estimates for the probability of survival at 36 months are shown. Vertical ticks represent censored patients. $p=0.07$. asplenic status, thrombosis and left heart disease (with a diastolic component) may share a role in vascular damage. The implication of our findings are particularly important if a specific therapeutic approach for the management of $\mathrm{PH}$ is considered, as treatments for pre- and post-capillary PH may be considerably different. The clinical results of controlled trials of endothelin receptor antagonists use in heart failure have been disappointing so far, despite their proven efficacy in pulmonary arterial hypertension [20, 21].

Moreover, several considerations of the pathophysiology of $\mathrm{PH}$ in SCD have emphasised only the role of haemolysis and pulmonary vasoconstriction in the genesis of this complication. In fact, our study found a very similar pattern to those observed in other studies. Although it has been questioned [22], there is evidence of a role of haemolysis in the pathogenesis of $\mathrm{PH}$ in $\mathrm{SCD}$. Our study also confirms the impact of $\mathrm{PH}$ on the mortality of SCD patients.

Nonetheless, it is relevant to consider other factors. The haemodynamic profile has some patterns already described in the literature $[17,23]$. PVR is markedly low, if compared with other populations of PH patients [24]. The mean PVR in this group was 2.3 Wood units and the highest PVR was 5.1 Wood units. In the

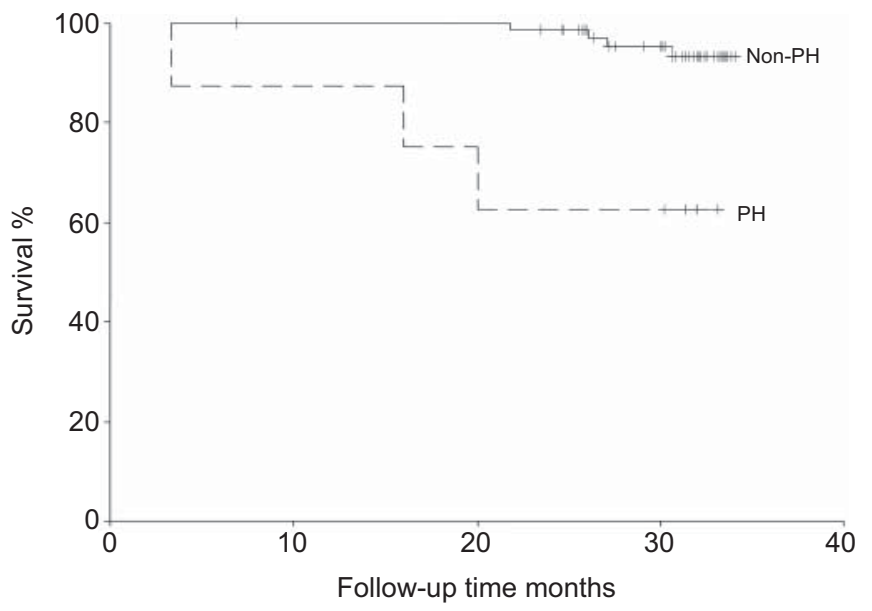

FIGURE 3. Probability of survival according to confirmed diagnosis of pulmonary hypertension $(\mathrm{PH})$. Kaplan-Meier estimates for the probability of survival at 36 months. Vertical ticks represent censored patients. $p=0.0005$. 
group without $\mathrm{PH}$, the mean PVR was 0.78 Wood units, which is much lower than the usual reference value of 1.7 Wood units [25]. These findings are attributable to the lower viscosity and the decreased vascular resistance in response to high CO secondary to the treatment regimen of chronic anaemia $[17,26]$.

When individuals with $\mathrm{PH}$ are compared with the remaining patients, differences in clinical, haematological, biochemical and functional characteristics become more evident. It is noteworthy that uric acid is elevated $(512 \pm 78$ versus $306 \pm 99 \mathrm{mmol}$. $\left.\mathrm{L}^{-1} ; \mathrm{p}<0.0001\right)$ and platelet count is decreased $(284 \pm 129$ versus $422 \pm 122 \times 10^{9}$ cells $\left.\cdot \mathrm{L}^{-1} ; \mathrm{p}=0.0015\right)$ in the $\mathrm{PH}$ group.

High levels of uric acid have been observed in patients with other forms of $\mathrm{PH}$ and were assigned to the depletion of adenosine triphosphate in the tissues and worsening of oxidative metabolism [27]. Hyperuricaemia also occurs in haemolytic disease as a consequence of the increased production of uric acid after the recycling of purines. Associated renal dysfunction may also be related to increased uric acid level [28].

The decrease in platelet count was not expected in a context of an inflammatory disease and the presence of hyposplenism. It is not possible, however, to exclude that lower platelet counts could be associated with the presence of hepatitis $C$ or older age, as already described in SCD [29,30]. Although our study evidenced older age in this subgroup of patients, no association with hepatitis $\mathrm{C}$ could be noted.

Survival was significantly lower in the group with $\mathrm{PH}$ confirmed by RHC, regardless of the haemodynamic pattern (pre- or post-capillary). This finding is particularly relevant and raises the importance of the appropriate diagnosis of $\mathrm{PH}$ in this particular subgroup of patients.

Our study has some limitations that need to be accounted for. The monocentric design and small sample size should be taken into consideration when extrapolating our results. To allow us to better scrutinise our results, 95\% CIs were included. Moreover, not all patients selected for completion of catheterisation could be subjected to the procedure. Even under these limitations, to our knowledge, our study presented the largest proportion of individuals evaluated by invasive haemodynamic assessment.

We conclude that $\mathrm{PH}$ is a significant complication of SCD with direct prognostic implications. Our study reinforces the use of echocardiography as a screening tool for PH in SCD patients and the mandatory role of RHC for the proper diagnosis. The higher prevalence of post-capillary $\mathrm{PH}$ associated with SCD strengthens not only the evidence for multifactorial pathways that may be involved with this particular clinical condition but also the need for appropriate haemodynamic characterisation before any attempt at a specific therapeutic approach targeting $\mathrm{PH}$ management.

\section{STATEMENT OF INTEREST}

None declared.

\section{REFERENCES}

1 Stuart MJ, Nagel RL. Sickle cell disease. Lancet 2004; 364: 1343-1360.

2 Bunn HF. Human hemoglobin: sickle hemoglobin and other mutants. In: Stamatoyannopoulos G, Majerus PW, Perlmutter RM, et al., eds. The Molecular Basis of Blood Diseases. 3rd Edn. Philadelphia, WB Saunders, 2002; pp. 227-274.

3 World Health Organization. Sickle Cell Anaemia: Report by the Secretariat - provisional agenda - item 11.4. Geneva, WHO, 2006.

4 Yater WM, Hansmann GH. Sickle cell anemia: a new cause of cor pulmonale: report of two cases with numerous disseminated occlusions of the small pulmonary arteries. Am J Med Sci 1936; 191: 474-484.

5 Powars DR, Weidman JA, Odom-Maryon T, et al. Sickle cell chronic lung disease: prior morbidity and the risk of pulmonary failure. Medicine 1988; 67: 66-76.

6 Castro O. Systemic fat embolism and pulmonary hypertension in sickle cell disease. Hematol Oncol Clin North Am 1996; 10: 1289-1303.

7 Reiter CD, Wang X, Tanus-Santos JE, et al. Cell-free hemoglobin limits bioavailability in crickle cell-disease. Nat Med 2002; 8: 1383-1389.

8 Rother RP, Bell L, Hillmen $\mathrm{P}$, et al. The clinical sequelae of intravascular hemolysis and extracellular plasma hemoglobin: a novel mechanism of human disease. JAMA 2005; 293: 1653-1662.

9 Galié N, Manes A, Branzi A. Evaluation of pulmonary arterial hypertension. Curr Opin Cardiol 2004; 19: 575-581.

10 Al-Sukhun S, Aboubakr SE, Girgis RE, et al. Pulmonary hypertension is present in $10-30 \%$ of adults patients with sickle cell disease. Blood 2000; 96: Suppl. 1, 9a.

11 Ataga KI, Sood N, De Gent G, et al. Pulmonary hypertension in sickle cell disease. Am J Med 2004; 117: 665-669.

12 Covitz W, Espeland M, Gallagher D, et al. The heart in sickle cell anaemia. The Cooperative Study of Sickle Cell Disease (CSSCD). Chest 1995; 108: 1214-1219.

13 Gladwin MT, Sachdev V, Jison ML, et al. Pulmonary hypertension as a risk factor for death in patients with sickle cell disease. $N$ Engl J Med 2004; 350: 886-895.

14 De Castro LM, Jonassaint JC, Graham FL, et al. Pulmonary hypertension associated with sickle cell disease: clinical and laboratory endpoints and disease outcomes. Am J Hematol 2007; 83: $19-25$

15 ATS Committee on Proficiency Standards for Clinical Pulmonary Function Laboratories. ATS statement: guidelines for the sixminute walk test. Am J Respir Crit Care Med 2002; 166: 111-117.

16 Gottdiener JS, Bednarz J, Deveraux R, et al. American Society of Echocardiography recommendations for use of echocardiography in clinical trials - a report from the American Society of Echocardiography's Guidelines and Standards Committee and the Task Force on Echocardiography in Clinical Trials. J Am Soc Echocardiogr 2004; 17: 1086-1119.

17 Castro O, Hoque M, Brown BD. Pulmonary hypertension in sickle cell disease: cardiac catheterization results and survival. Blood 2003; 101: 1257-1261.

18 Anthi A, Machado RF, Jison ML, et al. Hemodynamic and functional assessment of sickle cell disease patients with pulmonary hypertension. Am J Respir Crit Care Med 2007; 175: 1272-1279.

19 Sachdev V, Machado RF, Shizukuda Y, et al. Diastolic dysfunction is an independent risk factor for death in patients with sickle cell disease. J Am Coll Cardiol 2007; 49: 472-479.

20 Packer M, McMurray J, Massie BM, et al. Clinical effects of endothelin receptor antagonism with bosentan in patients with severe chronic heart failure: results of a pilot study. J Card Fail 2005; 11: 12-20.

21 Anand I, McMurray J, Cohn JN, et al. Long-term effects of darusentan on left-ventricular remodelling and clinical outcomes in the Endothelin A Receptor Antagonist Trial in Heart Failure (EARTH): randomised, double-blind, placebo-controlled trial. Lancet 2004; 364: 347-354.

22 Bunn HF, Nathan DG, Dover GJ, et al. Pulmonary hypertension and nitric oxide depletion in sickle cell disease. Blood 2010; 116: 687-692. 
23 Leight L, Snider TH, Clifford GO, et al. Hemodynamic studies in sickle cell anaemia. Circulation 1954; 10: 653-662.

24 Souza R, Humbert M, Sztrymf B, et al. Pulmonary arterial hypertension associated with fenfluramine exposure: report of 109 cases. Eur Respir J 2008; 31: 343-348.

25 Barst RJ. Pulmonary hypertension. In: Goldman L, Ausiello D, eds. Cecil Textbook of Medicine. 22nd Edn. Philadelphia, Saunders Elsevier Inc., 2004; pp. 450-458.

26 Gladwin MT, Sachdev V, Ognibene FP. Pulmonary hypertension as a risk factor for death in patients with sickle cell disease. $N$ Engl J Med 2004; 350: 886-895.
27 Njaman W, Iesaki T, Iwama Y, et al. Serum uric acid as a prognostic predictor in pulmonary hypertension with connective tissue disease. Int Heart J 2007; 48: 523-532.

28 Diamond HS, Meisel AD, Holden D. The natural history of urate overproduction in sickle cell anaemia. Ann Intern Med 1979; 90: 725-727.

29 Morris J, Dunn D, Beckford M, et al. The hematology of homozygous sickle cell disease after the age of 40 years. $\mathrm{Br} \mathrm{J}$ Haematol 1991; 77: 382-385.

30 McKarrell TDH, Cohen HW, Billett HH. The older sickle cell patient. Am J Hematol 2004; 76: 101-106. 